\title{
JOURNAL OF CENTRAL EUROPEAN AFFAIRS
}

The following authoritative articles appeared in the October, 1962 issue of the Journal . . .

Baron von Stumm, Advocate of Feudal Capitalism Abraham Ascher

Bertha von Suttner and the Nobel Peace Prize Irwin Abrams

An Image of European Politics:

The People's Patriotic Movement Marvin Rintala

Right-Wing Radicalism in West Germany's Younger

Generation Volker Berghahn

The Central Apparatus of Poland's Communist Party Richard F. Staar Ivan Mestrovic (1833-1962) Bogdan Raditsa NOTES RECENT PERIODICAL LITERATURE BOOK REVIEWS

Published Quarterly at the University of Colorado, Boulder S. HARRISON THOMSON, EDITOR

Yearly Subscription $\$ 6.00$

Subscription Abroad $\$ \mathbf{\$ 7 . 0 0}$

Single copies $\$ 1.75$

\section{THE CHINA QUARTERLY}

The October-December issue contains extensive comments by a number of leading economic and political specialists (Alexander Eckstein, Yuan-li Wu, Kenneth Walker, G. F. Hudson, Michael Lindsay, Richard Walker) on Joseph Alsop's controversial thesis on the present domestic crisis in China.

We maintain our extensive coverage of intellectual developments under the new regime with a brilliant article by Joseph Levenson entitled 'The Place of Confucius in Communist China'. In our series on the fate of the intellectuals, Merle Goldman writes on the famous Hu Feng who was vilified in 1955 because, though a Party member, he demanded freedom of expression for writers.

Other topies include 'The Rectification Campaign at Peking University: May-June 1957' by René Goldman, 'Communist Language Policies for China's Ethnic Minorities', by Henry Schwarz and 'The "Next Generation" of Chinese Communist Leaders' by Donald W. Klein.

Subscriptions $\$ 3$ (students \$2) per year

THE CHINA QUARTERLY

Ilford Honse, 133 Oxford Street, London, W.1, England 


\section{UNIVERSITY PRESS}

\section{MEN AND NATIONS}

\section{By Louis J. Halle}

Men and Nations represents an effort to resume progress in the great tradition of political philosophy, to present a foundation for the continued progress of our societies. The philosophical system that resulted is proposed here as a basis for the understanding and teaching of politics. It is, however, a complete philosophy of life, not limited to politics. "This is an important, original book. It is written with an elegance and a lucidity that are not mere properties of style but reflect the qualities of a first-rate mind."-Hans $J$. Morgenthau. 244 pages. $\$ 4.75$

\section{THE SINO-SOVIET CONFLICT, 1956-1961}

\section{By Donald S. Zagoria}

What happens if the two most powerful partners in the Communist world cannot agree on basic issues of principle and policy? Donald $\mathbf{S}$. Zagoria, who was from 1951 to 1961 an analyst of Communist Bloc politics for the U.S. government, traces the development of serious conflict between the U.S.S.R. and China from the 20th Party Congress in 1956 to the 22nd Party Congress in late 1961. "Not a moment too soon comes this superbly researched, refreshingly sensible and surprisingly readable analysis..."-Max Frankel. 512 pages. $\$ 8.50$

\section{THE INTERNATIONAL SYSTEM: THEORETICAL ESSAYS}

\section{Edited by Klaus Knorr and Sidney Verba}

Representative samples of recent thinking on the subject of international systems theory by a group of younger scholars. These essays, which explore whether or not a theory of international relations can be created, were first presented at a symposium sponsored by the Center of International Studies at Princeton University. 242 pages. $\$ 5.00$

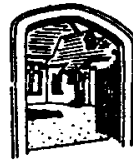




\section{Middle East, Asia, Europe ...}

\section{In books from Johns Hopkins}

\section{MODERN LIBYA: A Study in Political Develop- ment}

MAJID KhadDURI. First political history of the Libyan kingdom after World War II-an account of Libya's formation as an independent state; of her political, legal, and constitutional problems; and of her foreign relations. Here is expert appraisal of the political influence and effectiveness of each of the prime ministers. By the author of Islamic Jurisprudence and War and Peace in the Law of Islam.

\section{BRITAIN AND SOUTH-EAST ASIA}

SAUL Rose. Chronicle of Britain's fluctuating dominion in a crossroads of the world where for centuries she was the chief western power. Beginning with the first outposts of the East India Company, the narrative carries through Victorian empire-building, the collapse under Japan's lightning invasion, and into the turbid post-war involvements with Thailand, Burma, Malaya, Singapore, and the Borneo Territories. Second in the series, Britain in the World Today. 208 pages. $\$ 5.00$

\section{THE ECONOMIC DEVELOPMENT OF SPAIN}

Report of a Mission Organized by the International Bank for Reconstruction and Development. After long isolation, Spain is moving now toward closer integration with the European economy. This World Bank study focuses on the Spanish government's role in guiding the economy. It deals extensively with transportation, agriculture, industrial expansion, power supplies, education, housing, and the tourist trade. $43^{2}$ pages. $\$ 8.5^{\circ}$

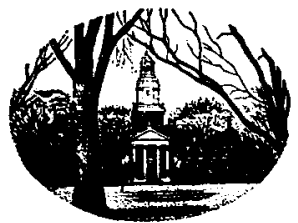

At your bookseller's . . . or from

\section{The Johns Hopkins Press, Baltimore 18, Md.}




\section{Of timely interest:}

\section{The Public Order of the Oceans}

\section{A Contemporary International Law of the Sea}

By Myres S. McDougal and William T. Burke. Following a tradition which antedates Grotius, the authors offer a comprehensive survey of the process of decision by which the general world community allocates access to, and authority over, the oceans during times of relative peace. In opposition to recent parochial claims of special interest, they bring the findings of modern physical and social science to bear in support of a public order of the oceans protecting the utmost freedom of access and widest possible sharing of authority. Previously published companion books: Studies in World Public Order, by Myres S. McDougal and Associates (\$15.00); Law and Minimum World Public Order, by Myres S. McDougal and Florentino P. Feliciano (\$12.50).

$\$ 15.00$

\section{American Foreign Policy and the Blessings of Liberty and Other Essays}

By Samuel Flagg Bemis. Gathered together in this volume are seventeen essays on American foreign policy and diplomacy selected from the many written by Samuel Flagg Bemis over the last fifty years. In all of the essays, which range over the whole span of American history, Mr. Bemis displays the careful research, imaginative reconstruction of events, and shrewd interpretation of individual and national motives that have made him one of America's foremost historians.

$\$ 10.00$

Yale University Press

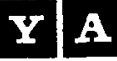

I $\mathbf{S}$

New Haven and London 


\section{$C_{\text {enter of }} \Phi_{\text {nternational }} \int_{\text {tudies }}^{\text {tud }}$}

PRINCETON UNIVERSITY

\section{ARMS CONTROL AND \\ THE PROBLEM OF EVASION}

BY JAMES K. BATTEN

This monograph deals with possible motives for evading an arms control agreement and with strategies for exploiting it.

Research Monograph No. 14

\section{UNITED STATES FOREIGN POLICY}

\section{IN A REVOLUTIONARY AGE}

By MORTON A. KAPLAN

A critical examination of past American foreign policy and a search for a more accurate and imaginative interpretation of the forces that are molding the present world and with which we, as well as other countries, must come to terms.

Policy Memorandum No. 25

\section{FURTHER NEW TITLES}

Chinese Communist Revolutionary Strategy, 1945-1949: Extracts from Volume IV of Mao Tse-tung's "Selected Works," by S. M. Chiu (Research Monograph No. 13)

$\$ 1.00$ Command and Control, by Thornton Read (Policy Memorandum No. 24) 


\title{
THE ASIAN ECONOMIC REVIEW
}

(Quarterly Journal of the Indian Institute of Economics)

EDITOR: PROF. S. V. AYYAR

VOLUME $\checkmark$

NOVEMBER 1962

NUMBER 1

\section{ARTICLES:}

ExDort Promotion and Economic Development in India-G. V. RAMAKRISHNA

Balanced Economic Growth-K. R. GUPTA

Finances of Andhro Districts between

1932-33 and 1953-54-M. L. KANTHA RAO

The Role of Extension Educotion in Economic Growth in an Under-

Developed Economy with Special Reference to the Community

Development Movement in india-R. S. MANI

Indo-Pakistan Trade-K. ANANTARAM

Population and Active Persons in the Indian State--V. V. BHANOJI RAO

2. BOOK REVIEWS

3. NOTES AND MEMORANDA
Per Copy-Rs. 5/-
U.S. $\$ 1.50-10$ sh. Sterling. U.S. $\$ 5.00-30$ sh. Sterling.
Published four times a year-November, February, May \& August.
Annual Subscription: Rs.20/-
REGISTRAR.
THE INDIAN INSTITUTE OF ECONOMICS.
HYDERABAD (A.P.) INDIA.

\section{INTERNATIONAL ORGANIZATION}

\author{
Contains in Volume 16, Number 4, Autumn 1962
}

\section{Articles}

Multilateral Versus Bilateral Aid: An Old Controversy Revisited Robert E. Asher

The Political Role of the Secretary-General Leland $M$. Goodrich

The Commonwealth and the United Nations Thomas B. Millar Federation in the Caribbean: An Attempt That Failed Hugh W. Springer The Single Convention on Norcotic Drugs, 1961 Adolf Lande

\section{Comprehensive Summories}

Recent activities of United Nations organs and of the specialized agencies Recent activities of major regional and functional organizotions

III. Selected Bibliography

Pertinent books and articles in American and foreign periodicals

\section{WORLD PEACE FOUNDATION \\ 40 Mt. Vernon Street \\ Boston 8, Mass., U.S.A.}




\section{Peasant Nationalism and Communist Power}

The Emergence of Revolutionary China, 1937-1945. Chalmets A. Johnson. "The author's contribution on all the problems involved is new, important, and independent. It cuts right across a number of old controversies."-Owen Lattimore

$\$ 5.75$

\section{Action Française}

Royalism and Reaction in Twentieth-Century France. Eugen Weber. Here is the complete story of this complex movement and its leaders from the end of the nineteenth century to the fall of the Vichy government.

$\$ 10.00$

\section{Moscow and Chinese Communists}

Second Edrrion. Robert C. North. First published in 1953, this work has been acclaimed as "the best short history of Chinese Communism yet published." The new edition now covers the first decade of Communist power in China from the point of view of Sino-Soviet relations.

$\$ 7.50$

\section{The Political Development of Tanganyika}

J. Clagett Taylor. This first political history of Tanganyika traces its development from the beginning of German colonization in the 1880 's to the attainment of independence. February. $\quad \$ 6.00$

\section{A History of Argentine Political Thought}

José Luis Romero. Introduction and Translation by Thomas $F$. McGann. Now in its third Spanish edition, this widely acclaimed book by one of Argentina's leading scholars gives the full sweep of the political development of Argentina.

$\$ 7.50$

Order from your bookstore, please STANFORD UNIVERSITY PRESS 


\section{N T ER NAT I O N A L S T UDIES}

Quarterly Journal of the Indian School of International Studies Sapru House, New Delhi-1

International Studies contains articles on modern International Politics, Economics, and Law as well as political, economic and social developments in Asia and other areas.

Editor: A. Appadorai

Vol. IV
Aesociate Editors: M. S. Venkataramani and V. P. Dutt

\section{CONTENTS No. 3 (January 1963)}

The Roosevelt Administration and the Great Indian Famine. M. S. Venkataramani

National Unity and Political Stability in Nigeria. S. N. Verma

Contemporary State Practice of India in the Fieid of International Law (1961). Nagendra Singh and M. K. Nawaz

Mr. Nehru, the Indian National Congress and India's Membership in the Commonwealth. Balram Singh Pavadya

Protection and Economic Development. D. Sumitra Bai

Survey of Source Materials: Political History of Modern Jordan. A. H. H. Abidi

Annual Subscription: Rs, 32, s. 60, $\$ 8.00$

Single Copy: $\quad$ Rs. 9, 8. $15, \$ 2.00$

Published by : ASIA PUBLISHING HOUSE

- Bombay * London * New York

An interdisciplinary journal for behavioral and social scientists who wish to keep abreast of research concerned with the problems of peace and international relations

\section{The Journal of}

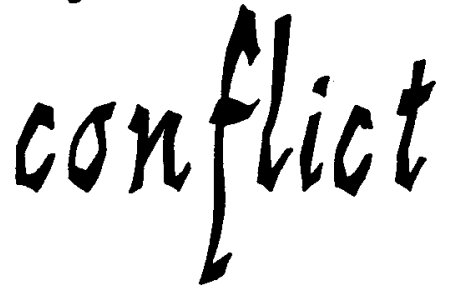

\section{R E S OLUTIO N}

A quarterly for research

related to war and peace

Annual subscription: $\$ 5.50$

per copy: $\$ 2.00$

Published by The Center for Research on Conflict Resolution 820 East Washington, University of Michigan, Ann Arbor, Michigan 


\section{Paperbound Books in}

Contemporary Governments

\section{THE GOVERNMENT OF REPUBLICAN ITALY}

John Clarke Adams, Syracuse University

Paolo Barile, University of Siena, Italy

245 pages

1962 Impression

$\$ 1.95$

BRITISH PARLIAMENTARY DEMOCRACY—Second Edition

Sydney D. Bailey

281 pages

1969

$\$ 1.95$

THE FEDERAL GOVERNMENT OF SWITZERLAND

George A. Codding, JR., University of Colorado

174 pages

1961

$\$ 1.95$

\section{GOVERNMENT AND POLITICS IN ISRAEL}

Oscar Kraines

246 pages

1961

$\$ 1.95$

\section{THE CONTEMPORARY GOVERNMENT OF JAPAN}

Theodore McNelly, University of Maryland

About 250 pages

A 1963 publication

\section{THE INDIAN POLITICAL SYSTEM}

Norman D. Palmer, University of Pennsylvania 277 pages 1961

\section{CONTEMPORARY GOVERNMENT OF GERMANY}

Elmer Plischke, University of Maryland

248 pages

1962 Impression

\section{Houghton Mifflín Company}




\section{Center of International Studies}

\section{涪- \\ Peace-Making and \\ the Settlement with Japan}

BY FREDERICK S. DUNN. This analytical case study of American decision-making draws on all the insights gathered during the author's career as a legal officer in the State Department and as director of the Yale Institute of International Studies and of the Center of International Studies at Princeton. It traces the evolution of American policies regarding peace with Japan from the early years of World War II through the negotiations that culminated in the treaty signed at San Francisco in 1951. Just published. 210 pp. $\$ 5.00$ The International System: Theoretical Essays, edited by Klaus Knorr and Sidney Verba. 1962. 237 pages. $\$ 5.00$

Deterrence and Defense: Toward a Theory of National Security, by Glenn H. Snyder. 1961. 294 pages. $\$ 6.50$

Order from your bookseller, or from

PRINCETON UNIVERSITY PRESS, PRINCETON, N.J.

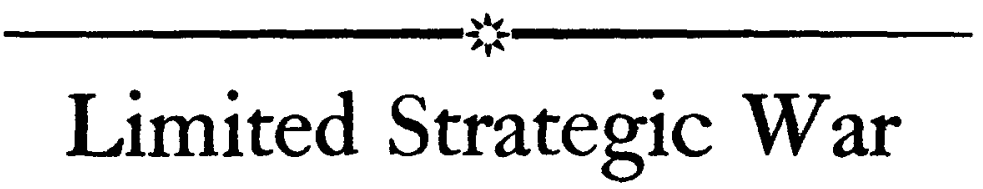

EDITED BY KLAUS KNORR AND THORNTON READ. "Knorr defines limited strategic war in the first article. The remaining essays, written by experts in the fields of nuclear warfare and political science, analyze various portions of the topic: controlled war, tactical war, command and control, limited retaliation as a bargaining process, alliances, and public attitudes. While not a book for light reading, this work presents some thought-provoking arguments and some new concepts."-Library Journal. 1962. 257 pages. \$6.00 $A$ Theory of Foreign Policy, by George Modelski. 1962. 152 pages. $\$ 5.00$ Guerrillas in the I960's, by Peter Paret and John W. Shy. 1961.82 pages. \$3.50

Order from your bookseller, or from

FREDERICK A. PRAEGER, Inc., 64 University Place, New York 3 